\title{
FACTORS AFFECTING PURCHASING INTENTION BY USING MOBILE SHOPPING APPLICATIONS IN MALAYSIA
}

\author{
Kah-Boon Lim* \\ Multimedia University \\ Sook-Fern Yeo \\ Multimedia University \\ Jin-Chee Wong \\ Multimedia University
}

\begin{abstract}
The increasing use of a smartphone to shop which is known as mobile commerce has become a new trend in the market. Majority of people have at least one smartphone in their hand due to the convenience of a smartphone. With the smartphone, smartphone users can easily download the mobile shopping applications and used the applications in their daily life. The main objective of this study is to investigate the factors affecting consumers' purchasing intention with the use of mobile shopping applications in Malaysia. The five factors that included in this study are perceived enjoyment, perceived usefulness, perceived ease of use, perceived trust and social influence while purchasing intention is the dependent variable. A set of selfadministered questionnaires has been circulated to 200 target respondents in Malaysia for data collection purpose. The major findings of this research showed that all the five independent variables have a significant relationship with purchasing intention. In conclusion, this research may help the mobile shopping applications marketers deeply developed better strategies to improve their business plan.
\end{abstract}

Keywords: Purchase intention, Mobile shopping applications, Perceived enjoyment, Perceived usefulness, Perceived ease of use.

Received: 9 July 2019

Accepted: 11 September 2020

\section{INTRODUCTION}

Nowadays, many companies and customers begin to sell or purchase the products or services through the mobile devices such as smartphone or tablets. This is in tandem with the increasing and widespread use of the smartphone and internet worldwide. This is generally known as mobile commerce (m-commerce) (Musa, Saidon, Harun, Adam, Dzahar, Haussain \& Lokman, 2016). Ecommerce refers to a transaction of selling and buying a product through electronic devices. Mobile commerce is a subset of the e-commerce where it goes through with the use of mobile devices. The increase of smartphone users has resulted in the increasing of the usage rate of mobile applications

- Corresponding author: Faculty of Business, Multimedia University, Jalan Ayer Keroh Lama, 75450 Melaka. Phone: +606-2523051; Email: kblim@mmu.edu.my 
(mobile apps) to meet the various needs of the consumer. The mobile apps can be defined as "small programs that run on a mobile device and perform tasks ranging from banking to gaming and web browsing" (Taylor. Voelker, \& Pentina 2011, p. 60). The invention of the mobile applications (mobile apps) makes consumers feel easier as they can directly click on the mobile apps to search for the information of the products as compared to browse or search through the website. Smartphone users can use the downloaded mobile apps to access the goods, compare the price, buy or sell the product, collect the loyalty point, track the parcel, write and read the reviews (Cruz \& McKenna, 2011).

There are some differences between shop through the browser and the smartphone devices. For example, some of the mobile shopping applications will provide the discount code to encourage the smartphone users to download the mobile shopping apps into their mobile devices and registered themselves as a new user for the mobile apps. In addition, there are a lot of retails companies in Malaysia have created their own mobile shopping applications such as Watson, eBay, Sephora, Lelong, Mudah, to name a few. Based on the survey report that provided by the Department of Statistics of Malaysia, the smartphone usage for internet access has increased to $97.7 \%$ in year 2017 compared to $97.5 \%$ in year 2015. Furthermore, the report also showed that $23.2 \%$ of the internet users performed e-commerce related activities such as purchase or order goods or services as their mainstream internet activity in year 2017. However, MasterCard Mobile Shopping Survey 2015 stated that Malaysia is still left behind compared to other Asia countries such as China. Since the mobile shopping applications have gradually become more well-known and acceptable in the marketplace, marketers have started to promote their brands and goods through apps (Gupta, 2013). According to Hutton and Rodnick (2009), apps are considered as a novel channel of brand communication.

As mobile shopping apps have become a new trend in Malaysia, the main objective of this study is to investigate the factors that affect consumers' purchasing intention by using the mobile shopping apps. This study is important to be conducted especially in developing countries such as Malaysia as it has the fastest growing mobile penetration rate in the world. The five factors which are included in this study are perceived usefulness, perceived enjoyment, perceived ease of use, perceived trust and social influence.

\section{LITERATURE REVIEW}

Technology Acceptance Model (TAM) is the most widely applied theory in the mobile marketing field of studies (Okazaki \& Barwise, 2011). According to Davis (1993), the Technology Acceptance Model is a well-accepted theory where the researchers used this theory to explain the user's intention to adopt technological innovations. In the study conducted by Davis (1989), TAM suggested that perceived usefulness (PU) and perceived ease of use (PEU) are the beliefs about a new technology that influence an individual's attitude towards and use of that technology. The usage intentions, drive adoption and subsequent usage behaviour can be influenced by all these beliefs. Besides that, Davis, Bagozzi and Warshaw (1992) defined perceived enjoyment (PE) as "the extent to which the people felt enjoy and will not consider all the consequences when using systems or computers". Nysveen, Pedersen and Thorbjørnsen (2005) also defined enjoyment as the degree to which it is pleasant when using the technology. Next, perceived trust (PT) can be defined as a person decide to trust on something, that a person is willing to be vulnerably harmed 
by others (Schoorman, Mayer, \& Davis, 2007). Perceived trust has been confirmed that play a vital role in the online shopping (Bilgihan, 2016). Al-Swidi, Behjati, and Shahzad (2012) also concluded that perceived trust is the important relationship between the seller and customers in the electronic commerce. Lastly, social influence (SI) can be defined as a person perceived by their family and friends that they should use a specific system (Venkatesh, Thong \& $\mathrm{Xu}, 2012$ ). According to the Al Kerdi, Alkhawlani, Aljounaidi and Mohamed (2017), a social influence which also refers to subjective norms is positively significant on the purchasing intention. Individual may also wish to impress their friends and family by emphasizing that they have make a purchase via mobile commerce (Shaw \& Sergueeva, 2019). Norzieiriani and Lawania (2018) have proved that perceived ease of use, perceived usefulness, social influence and perceived trust were found to affect Malaysia consumers' intention to use mobile marketing. Furthermore, their result also mentioned that social influence has the most impact on Malaysian purchasing intention compare to the other three factors. Tang (2020) concluded that perceived ease of use and perceived usefulness have positive influenced on purchase intention of mobile application users. Past research studies have proven the significant relationship of these five independent variables and purchase intention. However, there is a lack of theoretical and methodological clarity in evaluating purchase intention by using mobile shopping apps in Malaysia. The research framework of this study is shown in Figure 1.

Figure 1: Overview of the Model

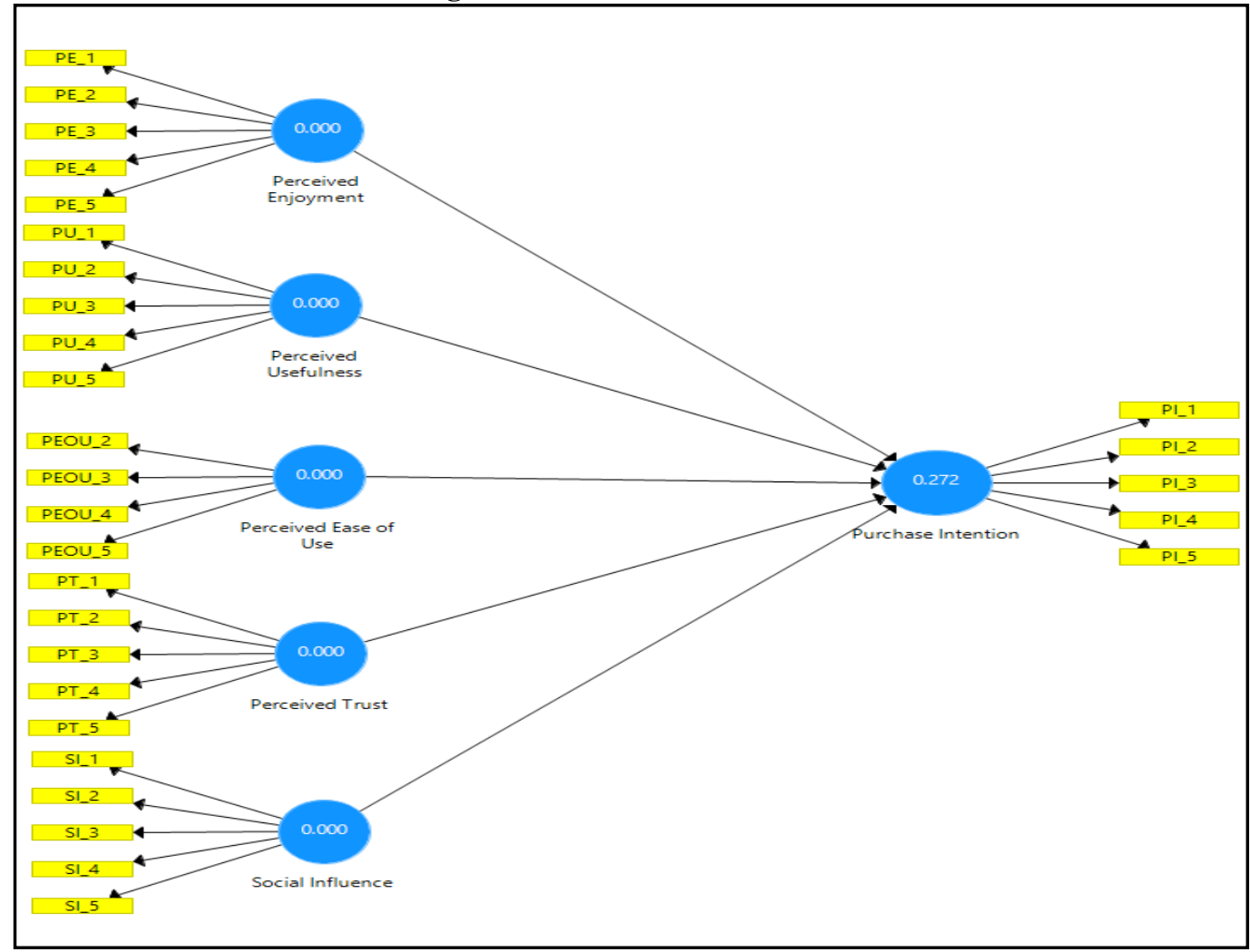


Hence, the five hypotheses tested in this study are:

H1: There is a significant relationship between perceived ease of use and purchasing intention by using mobile shopping applications.

$\mathrm{H} 2$ : There is a significant relationship between perceived enjoyment and purchasing intention by using mobile shopping applications.

H3: There is a significant relationship between perceived trust and purchasing intention by using mobile shopping applications.

H4: There is a significant relationship between perceived usefulness and purchasing intention by using mobile shopping applications.

H5: There is a significant relationship between social influence and purchasing intention by using mobile shopping applications.

\section{METHODOLOGY}

The convenience sampling technique is used in this study. According to Battaglia (2008), this technique is appropriate to be used during the data collection process due to its convenience and relatively low-cost factors. In this study, questionnaires are used in the data collection process. The minimum required sample size that calculated based on $\mathrm{G}^{*}$ power 3 is 66 respondents. However, Delice (2010) has mentioned that the larger sample sizes can give effect to the higher accuracy. In this research, the set of questionnaires have been distributed to 200 targeted respondents in the three states in Malaysia which covered Melaka, Johor Bahru and Selangor. The set of questionnaires that used in this study consists of two sections. Section A includes the demographic variables such as age, gender, monthly income level, occupation, education level and etc. Section B consists of the questionnaire items which used to measure five independent variables and the dependent variable. The five independent variables which included in this study are perceived enjoyment, perceived usefulness, perceived ease of use, perceived trust and social influence. The questionnaire items of perceived usefulness and perceived ease of use are adopted from Davis (1989). The questionnaire items of perceived enjoyment, perceived trust, social influence and purchase intention are adopted from Moon and Domina (2015). The collected data were keyed into SPSS version 25 and followed by using Partial Least Square Structural Equation Modeling (PLS-SEM 3.2.7) to assess the hypothesis.

\section{RESULTS AND DISCUSSION}

There are 200 of the survey questionnaires distributed to the consumers in Malaysia. There are 105 female respondents $(52.5 \%)$ and 95 male respondents (47.5) to participate in this survey. From the age group, it can be found that there are four groups namely 18-21, 22-25, 26-30 and 30 above. The 30 above $(16.5 \%)$ is the lowest respond age group compared to the $22-25$ age group is the highest respond that is $37.5 \%$. Most of the participant in this study are Malaysians (96\%). In addition, most of the respondents in this study obtained an average monthly income level of less than RM 1000 (36.5\%) and the lowest respondents are gained RM4, 000 and above (11\%). Besides that, most of the occupation category of the respondents are students at $70(35 \%)$, followed by private sectors, government servant and self-employed at $24 \%, 15 \%$ and $14.5 \%$ respectively. For the education level, the percentage for the respondents who had a higher education level degree is 
$50.5 \%$, followed by diploma which had 70 at 35\%, 26 respondents from other education levels and 3 respondents who were postgraduates.

The first step in the data analysis is to test the reliability and validity of the construct (Hair, Hult, Ringle, \& Sarstedt, 2017). All the item loadings are ranged from 0.651 to 0.859 as shown in Table 1. This indicates that all the item loadings are meeting the minimum requirement (Chin, 1998). However, PEOU_1 is removed due to its item loading value that does not meet the requirement of 0.5 (Chin, 1998). Furthermore, the result of composite reliability is ranged from 0.850 to 0.908 . This also showed that the measurement model is reliable and has adequate convergent reliability. Lastly, all the AVE values have exceeded the cut-off value of 0.5. To sum up, all the instruments that were used in this study have achieved the reliability and convergent validity conditions.

Table 1: Measurement Model

\begin{tabular}{|c|c|c|c|c|}
\hline Constructs & Question Items & Loadings & AVE & $\begin{array}{l}\text { Composite } \\
\text { Reliability }\end{array}$ \\
\hline \multirow{4}{*}{$\begin{array}{l}\text { Perceived ease of } \\
\text { use (PEOU) }\end{array}$} & PEOU_2 & 0.682 & \multirow{4}{*}{0.607} & \multirow{4}{*}{0.860} \\
\hline & PEOU_3 & 0.767 & & \\
\hline & PEOU_4 & 0.798 & & \\
\hline & PEOU 5 & 0.859 & & \\
\hline \multirow{5}{*}{$\begin{array}{c}\text { Perceived } \\
\text { enjoyment }(\mathrm{PE})\end{array}$} & PE_1 & 0.814 & \multirow{5}{*}{0.664} & \multirow{5}{*}{0.908} \\
\hline & PE_2 & 0.815 & & \\
\hline & $\mathrm{PE}_{-} 3$ & 0.818 & & \\
\hline & PE_4 & 0.850 & & \\
\hline & PE 5 & 0.777 & & \\
\hline \multirow{5}{*}{$\begin{array}{l}\text { Purchase intention } \\
\text { (PI) }\end{array}$} & PI_1 & 0.651 & \multirow{5}{*}{0.533} & \multirow{5}{*}{0.850} \\
\hline & PI_2 & 0.791 & & \\
\hline & PI_3 & 0.676 & & \\
\hline & PI_4 & 0.765 & & \\
\hline & PI 5 & 0.757 & & \\
\hline \multirow{5}{*}{$\begin{array}{l}\text { Perceived trust } \\
\text { (PT) }\end{array}$} & PT_1 & 0.810 & \multirow{5}{*}{0.652} & \multirow{5}{*}{0.903} \\
\hline & PT_2 & 0.850 & & \\
\hline & $\mathrm{PT}_{-}^{-} 3$ & 0.725 & & \\
\hline & $\mathrm{PT}_{-} 4$ & 0.839 & & \\
\hline & $\mathrm{PT} 5$ & 0.808 & & \\
\hline \multirow{5}{*}{$\begin{array}{c}\text { Perceived } \\
\text { usefulness (PU) }\end{array}$} & PU_1 & 0.719 & \multirow{5}{*}{0.621} & \multirow{5}{*}{0.891} \\
\hline & PU_2 & 0.787 & & \\
\hline & PU_3 & 0.829 & & \\
\hline & PU_4 & 0.832 & & \\
\hline & PU_5 & 0.768 & & \\
\hline \multirow{5}{*}{$\begin{array}{l}\text { Social influence } \\
\text { (SI) }\end{array}$} & SI_1 & 0.651 & \multirow{5}{*}{0.586} & \multirow{5}{*}{0.876} \\
\hline & SI_2 & 0.847 & & \\
\hline & SI_3 & 0.787 & & \\
\hline & SI_4 & 0.739 & & \\
\hline & SI 5 & 0.791 & & \\
\hline
\end{tabular}


Table 2 shows that the square root of the AVE value for each construct has exceeded its correlation with other constructs. This indicates that our model is sufficient support for discriminant validity at the construct level (Fornell \& Larcker, 1981).

Table 2: Discriminant Validity of Constructs

\begin{tabular}{lllllll}
\hline \hline & PEOU & PE & PT & PU & PI & SI \\
\hline PEOU & 0.779 & & & & & \\
PE & 0.351 & 0.815 & & & & \\
PT & 0.374 & 0.731 & 0.807 & & & \\
PU & 0.383 & 0.791 & 0.700 & 0.788 & & \\
PI & 0.459 & 0.647 & 0.634 & 0.669 & 0.730 & 0.766 \\
SI & 0.383 & 0.616 & 0.658 & 0.715 & 0.620 & 0.60 \\
\hline \hline
\end{tabular}

Table 3 shows the loading and cross-loadings for the measurement model. All items show high loaded in relation to their respective constructs and low in relation to other constructs. This provides sufficient support regarding convergent validity at the item levels as suggested by Chin (1998).

Table 3: Loadings and Cross-Loadings for The Measurement Model

\begin{tabular}{ccccccc}
\hline \hline & $\begin{array}{c}\text { Perceived } \\
\text { Ease of Use } \\
\text { (PEOU) }\end{array}$ & $\begin{array}{c}\text { Perceived } \\
\text { Enjoyment } \\
\text { (PE) }\end{array}$ & $\begin{array}{c}\text { Purchase } \\
\text { Intention } \\
\text { (PI) }\end{array}$ & $\begin{array}{c}\text { Perceived } \\
\text { Trust (PT) }\end{array}$ & $\begin{array}{c}\text { Perceived } \\
\text { Usefulness } \\
(\text { PU) }\end{array}$ & $\begin{array}{c}\text { Social } \\
\text { Influence } \\
\text { (SI) }\end{array}$ \\
\hline PEOU_2 & $\mathbf{0 . 6 8 2}$ & 0.127 & 0.233 & 0.165 & 0.171 & 0.242 \\
PEOU_3 & $\mathbf{0 . 7 6 7}$ & 0.254 & 0.286 & 0.275 & 0.278 & 0.291 \\
PEOU_4 & $\mathbf{0 . 7 9 8}$ & 0.309 & 0.387 & 0.348 & 0.325 & 0.313 \\
PEOU_5 & $\mathbf{0 . 8 5 9}$ & 0.344 & 0.459 & 0.333 & 0.368 & 0.333 \\
\hline PE_1 & 0.218 & $\mathbf{0 . 8 1 4}$ & 0.424 & 0.576 & 0.599 & 0.466 \\
PE_2 & 0.229 & $\mathbf{0 . 8 1 5}$ & 0.466 & 0.570 & 0.636 & 0.493 \\
PE_3 & 0.252 & $\mathbf{0 . 8 1 8}$ & 0.556 & 0.547 & 0.612 & 0.482 \\
PE_4 & 0.341 & $\mathbf{0 . 8 5 0}$ & 0.568 & 0.638 & 0.701 & 0.523 \\
PE_5 & 0.360 & $\mathbf{0 . 7 7 7}$ & 0.582 & 0.634 & 0.658 & 0.532 \\
\hline PI_1 & 0.273 & 0.315 & $\mathbf{0 . 6 5 1}$ & 0.332 & 0.383 & 0.350 \\
PI_2 & 0.346 & 0.580 & $\mathbf{0 . 7 9 1}$ & 0.534 & 0.490 & 0.486 \\
PI_3 & 0.265 & 0.416 & $\mathbf{0 . 6 7 6}$ & 0.376 & 0.436 & 0.415 \\
PI_4 & 0.429 & 0.496 & $\mathbf{0 . 7 6 5}$ & 0.506 & 0.573 & 0.452 \\
PI_5 & 0.340 & 0.508 & $\mathbf{0 . 7 5 7}$ & 0.521 & 0.533 & 0.537 \\
\hline PT_1 & 0.362 & 0.560 & 0.436 & $\mathbf{0 . 8 1 0}$ & 0.538 & 0.525 \\
PT_2 & 0.288 & 0.702 & 0.548 & $\mathbf{0 . 8 5 0}$ & 0.592 & 0.594 \\
PT_3 & 0.244 & 0.447 & 0.409 & $\mathbf{0 . 7 2 5}$ & 0.440 & 0.489 \\
PT_4 & 0.324 & 0.604 & 0.583 & $\mathbf{0 . 8 3 9}$ & 0.654 & 0.524 \\
PT_5 & 0.295 & 0.606 & 0.546 & $\mathbf{0 . 8 0 8}$ & 0.571 & 0.525 \\
\hline PU_1 & 0.288 & 0.559 & 0.443 & 0.439 & $\mathbf{0 . 7 1 9}$ & 0.467 \\
PU_2 & 0.351 & 0.706 & 0.517 & 0.578 & $\mathbf{0 . 7 8 7}$ & 0.597 \\
& & & & & &
\end{tabular}




\begin{tabular}{lllllll} 
PU_3 & 0.346 & 0.646 & 0.530 & 0.626 & $\mathbf{0 . 8 2 9}$ & 0.576 \\
PU_4 & 0.272 & 0.653 & 0.588 & 0.570 & $\mathbf{0 . 8 3 2}$ & 0.624 \\
PU_5 & 0.259 & 0.551 & 0.545 & 0.534 & $\mathbf{0 . 7 6 8}$ & 0.539 \\
\hline SI_1 & 0.224 & 0.336 & 0.348 & 0.333 & 0.452 & $\mathbf{0 . 6 5 1}$ \\
SI_2 & 0.357 & 0.550 & 0.597 & 0.547 & 0.639 & $\mathbf{0 . 8 4 7}$ \\
SI_3 & 0.314 & 0.439 & 0.447 & 0.540 & 0.562 & $\mathbf{0 . 7 8 7}$ \\
SI_4 & 0.236 & 0.462 & 0.455 & 0.528 & 0.508 & $\mathbf{0 . 7 3 9}$ \\
SI_5 & 0.312 & 0.533 & 0.483 & 0.544 & 0.554 & $\mathbf{0 . 7 9 1}$ \\
\hline \hline
\end{tabular}

The goodness of the theoretical model is established by explained variance in the endogenous construct $\left(R^{2}\right)$ and the significance of the all path coefficients $(\beta)$ (Chin, 2010). The $R^{2}$ value of this study is 0.272 which indicates that $27.2 \%$ of total variation in the dependent variable which is purchase intention can be explained by the five independent variables. The summary of the hypothesis testing result is shown in Table 4.

TABLE 4: Results of The Hypothesis Testing

\begin{tabular}{|c|c|c|c|c|c|c|c|}
\hline Hypothesis & Path & $\begin{array}{l}\text { Beta } \\
\text { Value }\end{array}$ & $\begin{array}{l}\text { Standard } \\
\text { Error } \\
\text { (STERR) } \\
\end{array}$ & $\mathrm{t}$ - Value & $2.5 \%$ & $97.5 \%$ & Decision \\
\hline H1 & $\begin{array}{c}\text { Perceived } \\
\text { Ease of Use } \\
\text {-> Purchase } \\
\text { Intention }\end{array}$ & 0.184 & 0.059 & $3.137 * *$ & 0.080 & 0.290 & Supported \\
\hline $\mathrm{H} 2$ & $\begin{array}{c}\text { Perceived } \\
\text { Enjoyment } \\
\text {-> Purchase } \\
\text { Intention }\end{array}$ & 0.188 & 0.086 & $2.202 *$ & 0.033 & 0.357 & Supported \\
\hline $\mathrm{H} 3$ & $\begin{array}{l}\text { Perceived } \\
\text { Trust -> } \\
\text { Purchase } \\
\text { Intention }\end{array}$ & 0.165 & 0.086 & $1.923 *$ & -0.003 & 0.337 & Supported \\
\hline $\mathrm{H} 4$ & $\begin{array}{c}\text { Perceived } \\
\text { Usefulness } \\
\text {-> Purchase } \\
\text { Intention }\end{array}$ & 0.208 & 0.098 & $2.123 *$ & 0.011 & 0.390 & Supported \\
\hline H5 & $\begin{array}{c}\text { Social } \\
\text { Influence } \\
\text {-> Purchase } \\
\text { Intention }\end{array}$ & 0.176 & 0.087 & $2.017^{*}$ & 0.022 & 0.346 & Supported \\
\hline
\end{tabular}

$\overline{* * \mathrm{p}<0.01,{ }^{*} \mathrm{p}<0.05, \text { Bootstrapping }(\mathrm{n}=5000)}$

The hypotheses results showed that all the hypotheses are supported at a minimum of $5 \%$ significance level. All the independent variables showed a significant relationship on purchasing intention by using the mobile shopping applications.

Our result showed that there is a significant and positive relationship between perceived ease of use and purchase intention. Agrebi and Jallais (2015) concluded that people will have a good 
experience when they are the first to use mobile shopping applications if the content and information of the apps are simple and easy to understand. Based on the study by Natarajan, Balasubramanian and Kasilingam (2017) pointed out that perceived enjoyment can be explained as used a technology is pleasant no matter the consequence of any conceivable implementation. They have proved that the perceived enjoyment has a positive relationship toward purchase intention in their study. For the result of H3, our result is consistent with Musa et al., (2016). They also have proved that perceived trust has a positive impact on the customers' purchase intention. The fourth hypothesis investigates the relationship between perceived usefulness and purchasing intention by using mobile shopping applications. Natarajan, Balasubramanian and Kasilingam (2017) also proved that the relationship between perceived usefulness and the purchase intention by using mobile shopping applications. Lastly, our result of the social influence is consistent with Toh (2011). According to Toh (2011), social influence has positive relationship with the purchasing intention by using mobile shopping applications.

\section{CONCLUSION}

The main objective of this study is to investigate the factors affecting purchasing intention by using mobile shopping applications among the consumers in Malaysia. Our findings showed that consumer required a good combination of information and entertainment of the mobile shopping apps as these concerns will positively affect the consumers' purchasing intention by using the mobile shopping apps. This research finding can significantly benefit the mobile app marketers. Furthermore, the developer of mobile shopping apps should always update their system due to the fast development of technology so as to make sure the perceived usefulness of mobile shopping apps. Besides that, the mobile shopping apps developer should make sure that the design of mobile shopping apps is simple and user-friendly. The mobile shopping developer also suggests improving the privacy policy to protect the customer's personal information. Other than that, consumers will share their good experience with their friends or family about the apps if the mobile shopping apps can meet their requirement. The findings from this research can benefit the m-commerce sector and help to accelerate the e-commerce growth by 2020 together with the launched of the first regional and Malaysia e-hub, the Digital Free Trade Zone in 2017.

In conclusion, this research suggests that mobile shopping apps marketers should develop better strategies to improve their business plan. Furthermore, the marketers also can take advantage of our results to design the mobile shopping apps so as to attract consumers' attention and formulate effective marketing strategies.

\section{REFERENCES}

Agrebi, S., \& Jallais, J. (2015). Explain the intention to use smartphones for mobile shopping. Journal of Retailing and Consumer Services, 22, 16-23.

Al Kerdi, F., Alkhawlani, M. A. A., Aljounaidi, A., \& Mohamed, H. B. H. (2017). Customer Trust and Acceptance Of Online Purchasing In Malaysia. International Sciences of Management Journal, 1(1), 1-15. 
Al-Swidi, A. K., Behjati, S., \& Shahzad, A. (2012). Antecedents of Online Purchasing Intention among MBA Students: The Case of University Utara Malaysia Using the Partial Least Squares Approach. International Journal of Business and Management, 7(15), 35-49.

Battaglia, M. P. (2008). Nonprobability sampling. Encyclopedia of survey research methods, 1 , 523-526.

Bilgihan, A. (2016). Gen y customer loyalty in online shopping: An integrated model of trust, user experience and branding. Computers in Human Behavior, 61, 103-113. doi: https://doi.org/10.1016/j.chb.2016.03.014

Chin, W. W. (1998). The partial least squares approach to structural equation modelling. Modern methods for business research, 295(2), 295-336.

Chin, W.W. (2010). How to write up and report PLS analyzes. In Vinzi, V. E., Chin, W. W., Henseler, J., \& Wang, H. (Eds.), Handbook of Partial Least Squares, Berlin: Springer.

Cruz, B., \& McKenna, J. (2011). How Smartphones Are Changing the Retail Shopping Experience. Retrieved from papers2://publication/uuid/5AE8B6C2-5F9C-40D8-809DD1894E2ECF2B

Davis, F. D. (1989). Perceived Usefulness, Perceived Ease Of Use, And User Acceptance. MIS Quarterly, 13(3), 319-340.doi: https://doi.org/10.2307/249008

Davis, F. D. (1993). User acceptance of information technology: system characteristics, user perceptions and behavioural impacts. International Journal of Man-Machine Studies, 38(3), 475-487.

Davis, F. D., Bagozzi, R. P., \& Warshaw, P. R. (1992). Extrinsic and Intrinsic Motivation to Use Computers in the Workplace. Journal of Applied Social Psychology, 22(14), 1111-1132. doi: https://doi.org/10.1111/j.1559-1816.1992.tb00945.x

Delice, A. (2010). The Sampling Issues in Quantitative Research. Educational Sciences: Theory and Practice, 10(4), 2001-2018.

Fornell, C., \& Larcker, D. F. (1981). Evaluating structural equation models with unobservable variables and measurement error. Journal of Marketing Research, 18(1), 39-50.

Gupta, S. (2013, March). For Mobile Devices, Think Apps, Not Ads. (cover story). Harvard Business Review. Retrieved from https://hbr.org/2013/03/for-mobile-devices-think-appsnot-ads

Hair, J. F., Hult, G. T. M., Ringle, C. M., \& Sarstedt, M. (2017). A Primer on Partial Least Squares Structural Equation Modeling (PLS-SEM). ( $2^{\text {nd }}$ ed). California: SAGE Publication, Inc.

Hutton, G., \& Rodnick, S. (2009). Smartphone opens up new opportunities for smart marketing. Admap, 44(11), 22-24.

Moon, E., \& Domina, T. (2015). Willingness to use fashion mobile applications to purchase fashion products: A comparison between the United States and South Korea. Journal of Textile and Apparel, Technology and Management, 9(3), 1-15.

Musa, R., Saidon, J., Harun, M. H. M., Adam, A. A., Dzahar, D. F., Haussain, S. S., \& Lokman, W. M. W. (2016). The Predictors and Consequences of Consumers' Attitude Towards Mobile Shopping Application. Procedia Economics and Finance, 37(16), 447-452. doi: https://doi.org/10.1016/S2212-5671(16)30150-2

Natarajan, T., Balasubramanian, S. A., \& Kasilingam, D. L. (2017). Understanding the intention to use mobile shopping applications and its influence on price sensitivity. Journal of Retailing and Consumer Services, 37, 8-22. doi: https://doi.org/10.1016/j.jret conser.2017.02.010

Norzieiriani, A. \& Lawania, K. (2018). Factors Influencing Consumer Intention to Use Mobile Marketing. International Journal of Organisation \& Business Excellence, 3(1), 1 - 13. 
Nysveen, H., Pedersen, P. E., \& Thorbjørnsen, H. (2005). Explaining intention to use mobile chat services: moderating effects of gender. Journal of Consumer Marketing, 22(5), 247-256.

Okazaki, S., \& Barwise, P. (2011). Has the time finally come for the medium of the future? Research on mobile advertising. Journal of Advertising Research, 51(1), 59-71.

Schoorman, F. D., Mayer, R. C., \& Davis, J. H. (2007). An integrative model of organizational trust: Past, present, and future. Academy of Management Review, 32(2), 344-354. doi: https://doi.org/10.5465/AMR.2007.24348410

Shaw, N., \& Sergueeva, K. (2019). The non-monetary benefits of mobile commerce: Extending UTAUT2 with perceived value. International Journal of Information Management, 45, 4455.

Tang, I. X. E. (2020). Assessing Factors Affecting Purchase Intention of Mobile Application Users (Doctoral dissertation), Swinburne University of Technology Sarawak Campus, Malaysia

Taylor, D. G., Voelker, T. A., \& Pentina, I. (2011). Mobile application adoption by young adults: A social network perspective. IJMM Winter, 6(2),60-70. doi: http:digitalcommons.sacred heart.edu/wcob_fac/1

Toh, T. S. (2011). An Investigation on the Adoption of Online Apparel Shopping of Malaysian Generation Y. International Journal of Contemporary Hospitality Management, 3(1), 114. doi: http://eprints.utar.edu.my/705/1/MBA-2011-0902273-1.pdf

Venkatesh, V., Thong, J. Y., \& Xu, X. (2012). Consumer acceptance and use of information technology: extending the unified theory of acceptance and use of technology. MIS Quarterly, 36(1), 157-178. 